\title{
THE BALKAN CONCEPT OF THE PHENOMENON OF ODESSA CULTURE
}

\section{Halyna Stoyanova}

Associate professor, the Department of Archaeology and Ethnology of Ukraine, Odessa National I. I. Mechnikov University

e-mail: gzstoyanova@gmail.com

\begin{abstract}
This article explores manifestations of the Balkan concept as a component of the phenomenon of 'Odessa culture.' The research aims to reveal the concept's specific components, how they were formed in Odessa's sociocultural environment and how they are manifested today. These tasks are solved by means of retrospective analysis, one of the key methods of Historical Urban Studies. This form of analysis enables investigation of the issues of city development and functioning in a comprehensive fashion and implies an interdisciplinary approach. The process of populating Odessa and its ethnic composition shaped the 'Odessa culture' phenomenon. Its unique nature involves a harmonious blend of various social, ethnic and religious layers. Since Odessa was established as a city, the Balkan peoples have become an integral part of this process. The Balkan component is now cemented in the city's culture and is strongly reflected in its toponymy and social and cultural practices. The public activities of individuals and cultural communities contribute to the positive image of Balkan ethnicities. For example, the Balkan culinary tradition is an integral component of Odessans' everyday culture. All the investigated aspects (demographic, toponymic, personal, sociocultural, culinary) enable the process whereby the Balkan concept synthesizes with the 'Odessa culture' phenomenon to be revealed. Odessa culture today is unimaginable without its Balkan component.
\end{abstract}

Keywords: Balkan peoples, component, concept, Odessa, Odessa culture, phenomenon. 


\section{Introduction}

Today, the notion of the 'city' is used with a far wider meaning than simply referring to a certain locality: it is also multi-layered. It implies a unique collection of listed heritage buildings, a place where urban culture is being shaped, a power centre whose power extends to neighbouring territories, a centre of economic ties and a special sociocultural environment. Urban Studies have long been an interdisciplinary field of research, encompassing both the integrated discipline itself and the complex of various theoretical approaches and disciplinary traditions. The city has been studied by historians, sociologists, architects, geographers, ethnologists and social anthropologists. Here it is given a special place occupied by the research category of 'the city's image', which comprises several parameters, from the vital service systems or socio-economic activity to spiritual life, including various forms of leisure, and cultural and religious zones. This category is often exploited by the humanities, as it covers the complex of typical forms of the lives of the individual, social groups and society as a whole in association with living conditions.

Accordingly, the focus on certain types of sources and investigatory objectives may determine different images of the city: demographic (ways of forming populations and the dynamics of their composition); architectural and/or toponymic (constructions, buildings, streets); ethnic (ethnic groups, manifestations of ethnic components in various walks of urban life); poetic (fiction, including poetry and prose fiction); personal or biographical (biographies of outstanding personalities, visitors to and natives of the city); sociocultural (the sociocultural practices of city-dwellers); and virtual (Internet forums, blogs and social media communities that represent local identity). We place the emphasis only on such city image's aspects as the demographic, toponymic, personal, and sociocultural.

It is worth mentioning that although every city has its history, not every city has been lucky enough to create a unique culture that distinguishes it from other cities. The specific nature of Odessa (Ukraine) implies not only the history of its populating, forming, development, everyday life and holidays, but also the ethnic dimension of these processes.

The object of the research in the paper is the City of Odessa. The subject is manifestations of the Balkan concept as a component of the phenomenon that is 'Odessa culture'. I aim to track down the ways in which the Balkan components in the sociocultural environment of the city of Odessa are formed and how they manifest themselves now. The research tasks target individual components of 
the Balkan concept that was historically formed and that became an integral part of both Odessa as a whole and 'Odessa culture' in particular.

In the investigation of certain ethnic components of a specific urban culture, it seems appropriate to use the term 'concept'. I believe that this term captures both the aim and the tasks of the present research most accurately. Despite the category of a concept having been exploited in science since the Middle Ages, it was the late twentieth century that witnessed its apparent actualization. Initially, linguistics boosted the spreading of this category, though it is impossible to limit its applicability to one area alone. In various areas of humanitarian studies, concepts acquire various meanings and interpretations. Contemporary researchers tend to believe that 'concept' is close to people's mental worlds, and hence to culture and history, and that this is where its distinctive nature comes from. The most significant feature of a concept is the multidimensional and discreet cohesion of its meaning, which exists, however, in a continuous cultural and historical space. Therefore, 'concept' tends to cultural transmission from one subject category to another, which entitles it to be called the major means of cultural transmission (Ibragimova 2010: 29).

The research tasks set out above will be solved by means of retrospective analysis, which is seen as one of the key methods in Historical Urban Studies. It enables us to explore comprehensively the development and functioning of cities and involves an interdisciplinary approach.

The phenomenon of Odessa and the diversity of its residents has been drawing the attention of historians, local history experts and ethnographers for several centuries now. This interest has contributed to the considerable research heritage on different aspects of city studies. It includes not \$investigations into specific ritual practices and the everyday life of city's residents.

Contemporary domestic and overseas historiography has a well-substantiated premise about the polyethnic and multicultural nature of the city of Odessa (Gerligi 1999; Stanko 2002; Richardson 2008; Prigarin 2017). These investigations, which prove Odessa's polyethnic nature (Belousova and Volkova, 2002; Kalmakan 2002; Belousova and Berezin 2014), play a significant role here. Local history experts place the spotlight not only the city's ethnic component, but also on the everyday cultural life of Odessans (Gubar 2010a; Gubar 2010b; Dontsova 2016).

However, historiography provides only a fragmented presentation of the history of individual Balkan ethnicities in Odessa (Kisse 2006; Berber 2019). Therefore, 
this article will be largely focused on the Balkan concept as a whole, its place in the city's evolution and how it has shaped the phenomenon of Odessa culture, revealed through the lens of the concept's specific components.

The components of the Balkan concept

Historically, modalities of settlement and ethnic composition of Odessa have become the basis for shaping the so-called 'Odessa' phenomenon. Its distinguishing and unique nature is provided by the seamless integration of many components that at first sight might seem barely compatible: various social, ethnic and religious layers. What also matters in forming a unique image of Odessa is, among others and equally importantly, the Balkan concept. Its manifestations are often subtle and not particularly visual in revealing their deep historical roots.

Furthermore, I shall outline the key components of the Balkan concepts that were formed historically and have become an integral part of Odessa's image as a whole, and 'Odessa culture' in particular.

\section{The first component is demographic.}

This is determined by the historical events and processes of the city's settlement.

Southern Palmyra, Black Sea Babylon, Small Paris, the Capital of the South - Odessa was assigned many epithets. And with reason. The city had barely started when the visitors watching the first port piles being driven down predicted a prominent future for the place.

A. Pushkin portrays Odessa in the most informative, yet laconic way (quite apart from the poetic beauty of the piece). His 'Odessa's portrait' provides a much better understanding of the vibes, spirit and mystery of the city than any voluminous historical treatise:

‘...The tongue of golden Italy

resounds along the gay street where

walks the proud Slav,

Frenchman, Spaniard, Armenian,

and Greek, and the heavy Moldavian,

and the son of Egyptian soil,

the retired Corsair, Morali...' (translated by V. Nabokov) 
Following Pushkin, many renowned writers, artists, musicians, actors, scientists and public figures became 'portrayers' of Odessa ( $\mathrm{V}$ chem zhe fenomen Odessy?).

The American researcher Patricia Gerligi, analysing the demographic development of Odessa in the nineteenth century, emphasized the key role of newcomers as a factor in the city's population (Gerligi 1999: 226-33).

The rise of Odessa made it appealing for numerous migrants. In many Russian provinces, there were rumours about the city that was seeking a workforce and offered tempting opportunities for the pursuit of trade and crafts. The Ukrainian historian O.P. Ogloblin pointed out that within the Porto Franco, wages in Odessa were higher than in England or in any other country (Ogloblin 1928: 42).

In the early nineteenth century, expatriate migrants from overseas played a significant role in the economy, culture and other areas of Odessa's urban life. Many foreigners arrived in the city from lands controlled by Turkey, where they had suffered various forms of repression. Among those who resettled from this country and the territories it had invaded and occupied were Greeks, Bulgarians and Serbs.

These Balkan migrants were among the first residents of this glorious Black Sea city, supporting the idea that the first Balkan component of the image and culture of the city is, of course, a demographic one.

Greeks. When speaking about Greeks, it is important to mention that it was not only the urban colonies they founded in the northern Black Sea region that made such a great contribution to the cultural development of the region. Much later, when Odessa has been founded and developed further, the Greeks were fully engaged in this process too. By investing money in construction and even managing the city successfully, they made a considerable contribution to Odessa's development.

Once the Russian army had seized the Turkish fortress of Khadzhybey and Odessa has been founded (the city was named after the ancient town of Odessos, a colony of Miletus), the Greeks went there to settle. The very first residents to create a Greek community in the city were the Ragtopolou, Gorgoli, Stamati, Lambrou, Maurokardatou, Skarlatou, Chrithomali, Linardatou and other families, a total of twenty families. In 1795, Odessa hosted 223 Greek nationals, in 1796 three thousand and in 1910 ten thousand, out of Odessa's 
then total population of 550,000). The Greek language was spoken by 5013 people (Nun 'yes 2007: 64).

The Greeks were among the largest merchants to play a major role in Odessa's foreign trade. They launched banking and small trading enterprises in the area, owned industrial enterprises, with small-scale production and crafts, as well as hotels and restaurants. They had a reputation as savvy bakers. Many of them are commemorated in the history of Odessa, such as D. Paleolog, P. Rodokanaki, G. Marazlis and M. Krion (Stanko 2002: 104).

The representatives of Odessa's Greek community were major contributors to the struggle for the national liberation of the Greek people from Ottoman rule. Here, on this coast of the Black Sea, was born the patriotic force that went on to deliver independence for Greece. And in this struggle, the Greeks fought shoulder to shoulder together with their co-religionists - Russians, Bulgarians, Serbs and Ukrainian (Black Sea) Cossacks. They laid down their lives for liberating the Balkan peoples.

The Greek diaspora in Odessa thus made a major contribution to the establishment and development of Odessa as a port city. Moreover, Greeks occupied a prominent place in Russia's trading relations with many countries around the world. The activities of the famous Greek merchants drove the international trading network, with Odessa becoming the maritime gates to the south of the Russian Empire.

Bulgarians. After the fall of the Izmail Fortress in December 1790, some Bulgarians, having resided in Izmail, moved to the outskirts of Khadzhybey. This was the first step toward a Bulgarian presence in the city of Odessa.

The first-ever census in Odessa was held on 25 July 1795. It recorded the fact that, at that moment, sixty Bulgarian nationals - 33 males and 27 females - had settled on the land of General De Vitte. Two years later, a report by the Novorossian Governor-General mentions that the Bulgarians had come there after the seizure of the Izmail Fortress and are very poor. They are therefore pleading for permission to settle there permanently as registered residents of Odessa.

According to Odessa's general layout at that time, within the city borders was a settlement called Bulgarka, populated by those 33 men and 37 women. In her book Moldovanka, Tetiana Dontsova states: 'Despite the stereotype, it must be admitted that the Moldovans were not the pioneers who settled in the Vodyana Balka. The role of the local first settlers rightfully belongs to the Bulgarians who founded Mala Bulgarka. The left bank of the Vodyana Balka 
had become the cradle of Odessa Bulgarians long before the right bank had a Moldovan settlement' (Dontsova 2016: 24). This is a reference to those sixty Bulgarian nationals who had left Izmail and become the founders of the Bulgarka area that lasted for as long as a hundred years, from the late eighteenth to the late nineteenth century.

In the early nineteenth century, the Bulgarka area welcomed new Bulgarian families from the neighbouring Kubanks, Velykyi and Malyi Buyalyk - the Hospodynovs, Dobrevs, Ivanovs, Serbinovs, Mikulovs and Bulgarovs.

In the late eighteenth to early nineteenth century, Odessa attracted many Bulgarian-born merchants of the third guild. In 1800, the Odessa Magistrates's newsletter contained records of the merchants of the third guild Ivan Vrazov, Ivan Ivani, Ivan Anturov and Kosta sin Dimo. In the first decade of the nineteenth century, Odessa became the home of future philanthropists and prominent figures of the Bulgarian Renaissance, Mykhola Spyrydonov Palauzov and Vasil Yevstafiev Aprilov.

In the 1860s, Mykola Myronovych Toshkov, Vasyl Rasheyev and Mykola Krystoforovych Palauzov owned almost an entire block of what is now downtown Odessa, bounded by what are now Dvorianska, Nizhynska, Leo Tolstoy and Novoselskoho streets. This block used to be called 'the Bulgarian block'.

In Odessa, Bulgarians were merchants of different sizes, civil servants in various departments, craftspeople and ordinary workmen. There were some highly extended families, as well as others that were elementary families. The parish registrars of the Greek Church of Saint Trinity, the parish serving the Bulgarians, have records that shed the light on some aspects of the everyday lives of the ordinary people. For instance, there is a record of Mykola, the illegitimate son of the Odessa craftswoman Kateryna Vasylivna Bolharova. There are many records about the holders of the Bulgarian surname Somliev, who often served as bridesmaids or best men at the weddings or as the godparents of new-born Bulgarians in Odessa.

Albanians. The path that brought Albanians to Ukraine was long and full of obstacles. The first Albanian settlers appear in Ukraine in the second half of the eighteenth century, when in 1778 the Greek army, created by S. Mavromichalis and comprising, among others, Albanians, was posted to the Crimea. Escaping from Ottoman oppression, many migrants from the Balkan peninsula, including Albanians, would settle in the Russian Empire. During the first years after Odessa's foundation, Albanians came here from the Crimea 
and Bulgaria. The archival records mention 'Commissions for the settlement of Greeks and Albanians' (Nun 'yes 2007: 22). In the reign of Catherine II, the city built houses for the Albanians, who were locally referred to as Arnauts. The first houses were constructed in the so-called 'Arnaut Sloboda'. In 1818, the Albanians gained the status of colonists. They had a compact settlement in what are now Velyka Arnautska and Mala Arnautska streets. The temper of the settlers and their guests (the Albanians used to exploit their houses as inns) were often mentioned on the crime news (Kesmendzhi).

The term 'Arnaut' requires a more detailed explanation. In the Ottoman Empire, it used to be the nickname for any Christian who had served in the Turkish army. One explanation argues that the Ottomans used the word 'Arnaut' to refer to members of the 'Greek army', who were accurate marksmen and strong warriors. As a rule, these were actually Albanians (Zhecheva et al. 2014: 172). In the late eighteenth and early nineteenth centuries, the name 'Arnaut' was reserved for Orthodox Greeks and other Balkan nationals who fled from the Ottoman Empire to the lands that had been recovered by the Russian Empire during the Russian-Ottoman wars in the second part of the eighteenth century (Kesmendzhi).

Serbs. After Turks occupied the Balkans in the seventeenth century, the Serbs were among those Christian refugees who fled to Ukraine. Initially, there were just a handful of such individuals. The first Serbian settlements in the Odessa region emerged after the defeat of the Serbian rebels against the Turks. This was the city to which the Serbian escapees from Montenegro would come to. In 1805, 22 families (a hundred people) from the Montenegrin village of Trebesa, which had been destroyed by the Turks, founded Serbka, while twelve families (ninety people) from the village of Humatsa became the founders of Chornogorka (Nun'yes 2007: 132).

Odessa became a home for Serbian merchants, scientists and cultural figures. 1891 witnessed the foundation of the Serbian Benevolent Association. Back then, the Kingdom of Serbia had a consulate in Odessa, and during WWI, the staff of the Serbian Volunteer Corps was located there. After the events of 1917, most of the Serbs were evacuated together with the White Guardists. Those who remained in the region vanished in the gloom of the Russian Revolution.

Summing up, we can generally agree with the quote of the famous Serbian researcher L. Tserovich on the history of the local Serbs: 'Odessa no longer has any Serbs. They are a part of history now' (Tserovich 2002). 


\section{The second component is toponymic or spatial}

The formation of the city's ethnic composition is reflected in its toponymy. Streets are the foundation of any city or town, the witnesses and keepers of various pages of its history. Odessa is no an exception here.

Among the names of Odessa's streets, one can find Hretska (the Greek; both street and square), Velyka and Mala Arnautska (referred to above), and Bolharska (Bulgarian).

Hretska (Greek) street is one of the oldest in the city. It received its name from the fact that most of the people living here represented the city's largest ethnic communities, which were all Greek. Greek settlements had relocated here long before the seizure of the Khadzhybey Fortress. According to the local history expert Oleh Gubar, in the area of what is now 30 Hretska street there was a coffee shop run by Simon Asparidis, a Greek national. Gubar says that while the Khadzybey fortress was being fought over, Asparidis fled from the city and came back only five days later, on September 19. However, Oleksandr De Ribas thinks that Asparidis never left the city and was already back in his coffee shop on September 14. Simon Asparidis is believed to be the first restaurant-keeper in Odessa. Over the years, the street where his coffee shop was located was overwhelmingly inhabited by his fellow Greeks and became the central and most prominent of the city's streets. This was the residence for Greek entrepreneurs, with their many warehouses, such as the 'Mauromatis Grocery and Colonial Shop', 'Pefanis Butchery', ' Caliphotidis Brewery' and 'Teseoglou Barber Shop'. In the early twentieth century, Oleksandr De Ribas, a grandson of Odessa's founder, wrote: 'The Greek street has its peculiar fragrance. It smells like dates, nuts and oranges, and various colonial spices' (De Ribas 1995).

Hretska (Greek) Square is one of the oldest and largest squares in Odessa. Back in the times of the Khadzhybey settlement, the area that later became a square hosted a market place. The square's development started from the areas detached from what is now Hretska street, and later part of what is now Deribasivska street was attached to it. Most of the developers were Greeks Ioannopulou, Serafino, Papahadzhy, Rallis, Marazlis. This was the distinguishing feature that determined the street's name.

The history of Hretska Square dates back to François de Wollant, who drew up the first town plan for the then new city of Odessa. Echoing the architecture of ancient Rome, he decided to create several separate centres ('hearths') of 
urban life grouped around market places. Hretska Square became one such centre, as well as becoming the centre of the city's main trading artery. De Wollant's ideas were carried out by two architects, the brothers Francesco and Giovanni Frapolli. Construction and development started in the early nineteenth century, and by 1830 the merchants' stands in the Greek market had already been completed.

The poet Eduard Bahrytskyi once wrote:

The market would buzz all over Greek square,

And over the town, the dawns would be glowing

The coffee would steam and Pushkin would glare

At the blue-greyish sea never slowing.

One of the new locations for the leisure time of residents and guests in today's city is Hretskyi (Greek) Park, built by Greek philanthropists.

Arnaut Sloboda, Velyka and Mala Arnautska streets. Besides Moldavian Sloboda, the old city maps also feature the Arnaut Sloboda, which was started as early as 1791 . Once the war with the Turks was over, Platon Zubov, one of Odessa's founders, tasked Jose de Ribas with building houses for Greeks and Orthodox Albanians - the Arnauts. This is how Arnaut Sloboda started in Odessa (Malaya Arnautskaya...). Over the years, it was 'dissolved' in urban development. 'In the layout, the epicentre of the Arnaut Sloboda was in fact shaped like a square and bounded within what are today Bazarna, Kanatna, Panteleimonovska and Pushkinska streets' (Gubar 2010a: 25).

Odessa's citizens are aware that Velyka and Mala Arnautska streets were named after the Albanians, the first settlers in this area. However, according to Gubar, different people settled here: 'By de Ribas' order, these buildings were handed over to the Greek trustee Kes Oglou (Kesoglou) to accommodate Mediterranean settlers. Kesoglou, however, would settle not only Greeks, Albanians and South Slavs, but also people who had arrived from different regions of Russia and form overseas' (Gubar 2010a: 20).

Some Albanians, having settled in Odessa, joint the Russian army, while others engaged in handicrafts and commerce. It was then that the streets were divided. In what is now Velyka Arnautska stood the houses of sailors comprising tall Arnauts, and Mala Arnautska became the home for shorter men who served in the infantry and cavalry. Some of them settled in the village 
of Arnautovka, now called Alexandrovka (Vopros-otvet: otkuda proizoshli nazvaniya odesskikh ulits).

Bolgarska (Bulgarian) Street is a distinct example of toponomy. Despite popular belief, its name does not refer to the Bulgarians as a people, but to a specific Bulgarian family, the Bolgarovs (Bulgarovs), who settled here in the mid-1810s. Dmitry Bolgarov was a 'supervisor of the Moldavian Sloboda' as early as 1813 . Research by a well-known historian of Odessa and local history expert shows that on 15 June 1813, four plots of land of standard size were allocated in the Moldavan Sloboda, including one for 'Dmitry Bolgarov, the supervisor of the Moldavan Sloboda.' His name is likely to have been associated with the name of one of the streets in what is now Moldavanka district (Gubar 2010b: 32). There are records of several people with this surname, including property owners on the 'street named after them'.

In 1814, the Construction Committee issued an open letter to Evdokia Serbinova, also known as Bulgarova, allowing her to construct a house, which, however, was only built in 1829 . The Bulgarov-Serbinovs' land lot was located at the beginning of the future street. In the nineteenth century, the street appeared in the records and on maps as both Bolgarska (Bulgarian), and Serbinovskaya, a parallel naming in which Serbinovskaya emerged thanks to Mikhail Serbinov. It is assumed that the Bulgarov and Serbinov families, which become related, are believed to have come from the now-forgotten area of the city called Bulgarka (Dontsova 2016: 332).

\section{The third component - an individual component.}

This can be traced in the major endeavours many of these individuals made for the benefit of the city in different historical periods. In the urban environment, ethnicity acquires clear features if it is seen through the lens of the activities of the outstanding personalities who, on the one hand, were acknowledged thanks to their activities in a certain area (for instance, politics, civic endeavours, science etc,) and on the other hand added lustre to their ethnicity and are associated with it accordingly.

The Greeks made a significant contribution to the city's political, economic and cultural development. Remarkably, during the nineteenth century, Odessa was run by six people of Greek origin, indeed, since 1800, when Ioan Kafedzhi became the mayor. Ivan Ambrosiy (twice), Dmitry Inglezi and Konstantin 
Papudov were also elected city mayors (Nun 'yes 2007: 65). But the city mayor who played the greatest role in making Odessa Greeks famous was Hryhoriy Hryhorovych Marazlis, mayor of the city from 1878 to 1895 . Under his leadership, Odessa grew into a cultural, educational, academic and recreational centre in the south of the Russian Empire. During this period, the city opened a bacteriological laboratory, run by I.I.Mechnikov, a botanical garden, the Kuyalnik Resort, a public library, a central post office, a mental hospital, a Museum of Fine Arts, more than forty public and educational institutions, enterprises, shops and the Privoz market. Gas lighting and a tram became parts of city life. Many of these institutions were established at the expense of H. Marazlis himself and charitable contributions made by the Greek community. As the head of the Greek Benevolent Association, Hryhoriy Marazlis made sure that the Greek community provided all the necessary items and food to Greek immigrants. The way Odessa looks like today owes much to G. Marazlis as well.

In the early nineteenth century, Odessa welcomed prominent figures of the Bulgarian Renaissance, Mykhola Spyrydonov Palauzov and Vasil Yevstafiev Aprilov. Mykola Chrystoforovych Palauzov reached the highest position in the social hierarchy of Odessa: not only did he receive a noble title, he also served as the mayor of Odessa. He initiated and chaired the Odessa Bulgarian Board of Trustees (1854-1899), which published more books in the Bulgarian language than Bulgaria itself did at that time. From the 1840s to the 1860s, Odessa was one of the centres of the Bulgarian socio-political movement. First, in 1858 , Odessa was visited by the Bulgarian revolutionary Georgy Rakovsky, who wrote his 'Plan for the Liberation of Bulgaria' in the city. Later, in 1863, the Bulgarian poet and revolutionary Hristo Botev arrived here. Odessa also became the city where Ivan Vazov wrote his first short stories and began his novel Under the Yoke.

The list of today's famous Bulgarian figures includes the following individuals:

In the area of politics and civic activity, Anton Ivanovich Kisse, born in Yevhenovka, Tarutyno Raion, Odessa Oblast. He earned his university degree in Odessa. Today, he is a Ukrainian MP, the President of the Association of Bulgarians of Ukraine, President of the Wrestling Association of Odessa region, and initiator and active participant in various social and cultural events related to the Bulgarian community of Odessa.

Academia-wise, Volodymyr Nykyforovych Stanko, a renowned scientist, Doctor of Sciences in history, professor, Laureate of the State Prize of Ukraine. 
He was born into a Bulgarian family in the village of Ternivka in Mykolaiv Oblast. After earning a degree in history, he became not only a regular historian but also an outstanding archaeologist, ethnologist and founder of research and educational activities in Odessa. For many years he was the dean of the Faculty of History at Odessa National I.I. Mechnikov University (ONU). It was thanks to him that his faculty opened a Department of Archaeology and Ethnology of Ukraine. He also became the initiator and founding father of the scholarly school of ethnography in Odessa (Prigarin A.A., 2013). But he was particularly enthusiastic about Bulgarian Studies, founding the Odessa Scientific Society of Bulgarian Studies and the Department of Bulgarian Studies at the Philological Faculty of ONU. He was the author of numerous scientific publications on his native land and his ancestors, the Bulgarians. However, he believed that one could not be an expert on just one nation alone and that each community should be considered from the perspective of its cross-cultural interactions. His civic activity in the national and cultural movement of the Association of Bulgarians of Ukraine is substantial.

Another remarkable individual on this list is a man who turned his passion into good: the founder of the only Museum of Football History in Ukraine, now located in Odessa, Emanuil Ganev (widely known under his nickname Misha Bulgarin). Back in 2009, he established a Football Fanclub that exhibited items of football paraphernalia collected by Ganev over 35 years. (Klub bolelshchikov futbola ...). However, in 2013 a severe fire destroyed almost all these unique and rare exhibits. Ganev then initiated the establishment of 'Football History Square', featuring a monument to Ukrainians who had won a Golden Ball Award. Great enthusiasm and devotion to something you are keen on can work wonders! Thus, on 10 September 2016, the Museum was reopened to visitors. It is worth mentioning that the Internet portals that covered this event reported not only the official name of the creator of the Football Museum in Odessa, but also his 'popular' nickname, Misha Bolgarin (Muzey futbola snova ...).

However, it is not only prominent individuals of a certain ethnicity that have contributed to the positive image of a particular ethnic group within the city. This image is greatly promoted by civic societies, which at the public level create a favourable environment for the interaction of the ethnic community with representatives of both 'their' ethnic group and the government or society as a whole. This is why it deems appropriate to look at: 


\section{The fourth component, a sociocultural one.}

This unfolds through the lens of civic organizations' activities that have brought together different ethnic communities and supported their ethnic identities in the city.

The Greeks played an important role in founding the city and its port, promoting international trade and occupying key positions in local government. Some Greek entrepreneurial families - Rodokonakis, Ralis, Marazlis, Vuchina, etc. -occupies leading positions in the economic life of the city generation after generation and were proactive members of charitable associations before stepping into immortality in the history of Odessa (Stanko 2002: 213). However, the first-ever formal association of ethnic Greeks in Odessa was not concerned with charity or religious support in the diaspora, but about fighting for the independence of their ancestral homeland from the Ottoman Empire. 1814 was the year of the foundation of 'Filiki Eteria' (Greek for 'Union of Friends'), a secret society founded by N. Skufas, E. Xanthos and A. Tsakalov (Belousova 2017: 49). This event ushered the preparations for the 1821 Greek Revolution and contributed to the Greek idea that Odessa was 'their' city because this was where the fire of their freedom struggle was ignited. Among other Greek organizations that emerged later was the Greek Benevolent Association (founded in 1862), the Greek Public Assembly 'Anagennisi' (Greek for 'Renaissance'; 1907), the Mutual Association of Greek Servants (1910) and the the Greek Music and Literary Society 'Nea Zoe' (Greek for 'New Life'), established in 1918 by the students of the then Novorossiysk University with the assistance of the Greek club 'Omonia' (Greek for 'Concord') (Belousova 2017: 49).

In the late twentieth century, after a long break, in 1988 the first Greek organization in Ukraine emerged in Odessa - the Greek club 'Hellas'. The club was intended as a centre for the revival of the famous Greek traditions of Odessa and initiated by Aristotle Agafangelovich Papunidi (Nun 'yes 2007: 72). 'Hellas' became one of the first ethnic organizations in the city. The club was seen as the centre of a movement for the revival of Hellenism in Ukraine. Its members formerly controlled the restoration of the historic Greek building at 20 Chervony Lane and promoted the establishment of a Greek Cultural Centre. These days, the building is a home for the Filiki Eteria Museum, preserved since the late 1980s and early 1990s by the efforts of 'Hellada.' 'Hellada' activities drew the attention of the Greek government to Odessa, resulting in 
the opening of the Odessa branch of the Foundation of Greek Culture in 1994. The members of 'Hellada' made it a tradition to celebrate Greek national holidays, above all, Okhi Day and Independence Day. They also made significant efforts to popularize Greek language classes. They maintain active cooperation with other Greek organizations and societies of other national minorities at the municipal, regional and national levels. In particular, Hellada is an active member of the Union of Greeks of Ukraine and the Council of Representatives of National Cultural Societies of the Odessa Oblast at the Odessa Oblast State Administration.

What is more, Greek NGOs throughout the Odessa oblast come under the patronage of the Odessa Oblast Community of Greeks, established in 1994. The community cooperates with the Consulate General of Greece in Odessa and is a member of the Council of Representatives of National-Cultural Societies at the Department for Nationalities and Religions of the Oblast State Administration. It is also an active participant in all cultural events initiated by the local authorities. In 1999, it became a member of the Federation of Greek Societies of Ukraine (Nun 'yes 2007: 71).

Since October 2003, the community has been publishing a monthly newspaper, the Odyssos. The community also has a Women's Council, which organizes parties and festive events, as well as making national costumes. The community's youth organization organizes regular festive events, dance parties and language classes. The community runs the Club of Entrepreneurs, which became the basis for the Business Hub for Greek-Ukrainian Trade and Industrial Business.

Odessa houses not only Greek but also Bulgarian organizations that have allUkrainian status. First of all is the Association of Bulgarian National-Cultural Societies and Organizations of Ukraine, established in Odessa on 2 October 1993. Initially, it comprised only seven organizations that were operating at that time, but their number increased later. As was mentioned above, the President of the Association is A.I. Kisse. The Association's vision is to promote the national culture of Bulgarians living in Ukraine, support their cultural, spiritual, ethnic and socio-economic interests, and develop friendly relations between Ukraine and Bulgaria (Asotsiatsia na balgarite v Ukrayna). The Association's printed outlet is the all-Ukrainian weekly bulletin Obozrenie Plus.

Moreover, since 2007, the Congress of Bulgarians of Ukraine has been operating in Odessa (headed by Yu. Gramatik). In 2013, the Congress helped to bring the Bulgarian Drama Theatre in Odessa back to life. The theatre company 
includes Bessarabian Bulgarians, as well as Odessans, who united for a common cause - the revival of the Bulgarian theatre in Odessa. The creators of the theatre call it the Odessa Bulgarian Drama Theater - a modern theatre with a Bulgarian accent! (Odesskiy Bolgarskiy Dramaticheskiy teatr...).

In 2013, yet another Bulgarian NGO was registered in Odessa, the AllUkrainian Assembly of Bulgarians of Ukraine. It was headed by Dora Kostova, the editor-in-chief of the Bulgarian-language newspaper Roden Krai.

All these Odessa-based Bulgarian organizations have extensive networks of social and political ties.

It is also worth mentioning other infrastructural organizations of the Bulgarian community in Odessa, such as the Odessa Bulgarian Society (operating since 1989), the All-Ukrainian Centre of Bulgarian Culture (since 1999), the Ivan Vazov Library (since 1998) and 'Aktiv', a Bulgarian youth club (since 2008). These organizations are involved with various social groups of Bulgarians living in the city, ranging from children and young people to scientists and the community more generally. For example, thanks to the All-Ukrainian Centre of Bulgarian Culture, the city's Bulgarian community is able to come together and not only mark important historical dates, but also celebrate the traditional festivals. Sometimes the celebration goes beyond the cultural centre and the city itself becomes the venue of the celebration. For example, it has become a tradition to celebrate the spring festival Dovizhdane, Baba Marta by decorating the trees near the Opera House with white and red martenitsas and singing national Bulgarian songs and dances

The Serbs made the first attempt to start an ethnic association of their own back in 1885 but failed. Only in 1891 did the community manage to launch the Serbian Benevolent Society at Serbia's Consulate General in Odessa. Consul General G. Suppicic played an important role in the formation of this Society. Among its other founders was Prince Yu. Gagarin, A. Petrovic, G. Mitkevic and N. Markovic (Belousova 2017: 53). The aim of the organization was to help poor Serbs in Odessa and its suburbs, as well as any who were travelling through the city. The society's funds accumulated thanks to membership fees, donations, income from theatrical performances, family dinners and balls. Odessa ladies who took part in raising the Society's funds were given the title of the Society's philanthropists. At the request of Consul G. Suppicic in 1893-1919, the then Novorossiya University regularly handed over its assembly hall and 
large classrooms for public lectures for the benefit of the Serbian Benevolent Society (Belousova 2017: 54).

Present-day Ukrainian society in general and Odessa in particular is familiar with the culture of the Serbian people thanks to the 'Ukrainian-Serbian Society', am NGO registered in Odessa in 2004. The Society brings together mainly historians, linguists and creative intellectuals.

The Albanian cultural and educational society 'Rilindia' ('Renaissance') is involved in the preservation of the language and culture of the Albanians residing in present-day Ukraine. Since day one of its work in 1993, its activities have encompassed not only language-learning initiatives, but also the preservation of cultural monuments, literature and history, cultural contacts with Albanians living in other territories, and participation in international scientific and cultural events. Although the Society has only regional status (it is registered in the village of Zhovtneve (Karakurt), Bolgrad Raion, Odessa Oblast), its activities are covered not only on the local but also in the national and international media. It publishes its own newspaper, Rilindija, which features materials in the Albanian, Russian and Ukrainian languages (Nun 'yes 2007: 23).

The history of the settlement of Odessa and the shaping of its ethnic composition is also reflected in the local cuisine, which seamlessly combines various traditions - Ukrainian, Russian, Jewish, Central European, Caucasian and undoubtedly Balkan. Each of these components has added its own vibe, adapting experiences and customs to the local environment. Accordingly, it is impossible to ignore:

\section{The fifth component - a culinary one}

This can be traced in two dimensions: first, is the Balkan component of 'Odessa' cuisine; and second, there are ethnic restaurants with 'Balkan vibes', which existed formerly and are still run in the city today.

The Balkan substrate of Odessa's cuisine was formed primarily at the level of raw food materials. Bulgarians, who lived not only downtown but also on the outskirts of Odessa were renowned gardeners and winegrowers. They supplied greens, melons and gourds, as well as vegetables, to the Odessa markets. Bell pepper has since been called 'Bulgarian', even though by the twentieth century Bulgarians no longer had a monopoly in growing this vegetable. The Albanians in the south of Ukraine made type of spring wheat, called 'Arnautka', very popular. During the early years in Odessa, Greek fishermen supplied the 
city with a variety of fish. It is thanks to them that Odessa's markets offered fresh mullet, bull, gloss and mussels, a choice that meets the needs of modern Odessa's residents as well.

The 'Balkan footprint' is also detectable in the catering system. Among the names for the city's catering facilities are 'tavern' (of Greek origin), korchma (from the Bulgarian word for a pub) and badega (of Romanesque origin) (Prigarin 2017: 172). For example, until recently at the crossing of Katerynenska and Gretska streets could be found the Bessarabian Bodega restaurant, which presented itself as a Bessarabian restaurant offering only local food and beverages.

The City Food Market (Misky Rynok Idy) serves local specialities, both foods and drinks. The staples of Greek cuisine (various olives, exclusive unrefined olive oil, feta, etc.) can be purchased from the Greek Shop at the New Bazaar. The chain of stores called 'Wines of the World' offers a variety of beverages. Besides a large assortment of drinks from all over the world for any taste and budget, there are exclusively Balkan drinks there, too, like Greek ouzo, plum, pear and all kinds of fruit brandy. According to the store staff, the most frequent buyers of the Bulgarian brandy rakiya are members of the Bulgarian ethnic community living in the city.

The local cuisine is served not only in dedicated cafes and restaurants but also in all-Ukrainian networks. In the variety of dishes that are offered, Balkan cuisine occupies a special place, with a selection of snacks with bryndza, various recipes for cooking mussels and vegetables; 'Greek' and 'Shopsky' salads are often on restaurant menus.

The menu of the famous restaurant Gambrinus features a salad called 'Salad for Senka-Greek'. It is a mix of bell peppers, cucumbers, tomatoes, olives, feta cheese, Crimean onions and olive oil. Traditional Greek cuisine can also be found on the menus of what are referred to as Mediterranean cuisine restaurants. There was once a Greek restaurant called Papa Costa on Hretska Street (now closed), while Hretska Square featured a Greek cafe called Elinikon. The Piteria restaurant served Greek dishes alongside European, Turkish and Arabic cuisine also.

With many catering facilities serving Balkan dishes as a part of their menu, there are also specialized restaurants focused on both Balkan cuisine in general and the cuisine of individual Balkan ethnic groups.

Besides the Bessarabian Bodega mentioned above, one can also mentioned a restaurant called Balkani. The restaurant's owners, in addressing prospective 
visitors, emphasize the known Odessa like of eating well and then assure them that they can satisfy it thanks to the most delicious Bulgarian cuisine, Bulgarian hospitality, famous Bulgarian wines, extraordinary dances, songs and incredible treats (Restoran Balkani...).

There are more cafes and restaurants with Bulgarian ethnic vibes, such as Mehana and Bessarabka. There used to be two more restaurants called Chotyry Bolharyna (Four Bulgarians) and Bessarabskyi Dvorik (Bessarabian courtyard) where one could try the taste of Bulgarian national cuisine in full, as well as drinks by both local Bessarabian and imported Bulgarian producers.

Even the exterior and interior designs of these establishments indicate or highlight their specific ethnic backgrounds. In Bessarabka, one can find a sophisticated combination of Ukrainian, Moldovan and Bulgarian cuisines, while Mehana presents itself as an exclusively Bulgarian restaurant with a history (founded in 1998) of specializing in authentic Bulgarian cuisine. For any restaurant with traditional cuisine, it is quite typical for there to be many Bulgarians among its guests (Bolgarskiy restoran s istoriey...).

\section{Conclusion}

Since Odessa emerged and evolved as a city, Balkan peoples have become an integral part of these processes. Thus is reflected in the fact that the Balkan component of the city is embedded in its culture and has obvious traces in its toponymics and social and cultural practices. The public activities of individuals and cultural communities contribute to the preservation of a positive image of these Balkan ethnicities. It is abundantly clear that the Balkan culinary tradition has become an integral part of the everyday cultural life of Odessans.

All the components we have looked at above (demographic, toponymic, personal, sociocultural and culinary) have enabled us to represent the process whereby the Balkan concept is synthesized with the phenomenon of 'Odessa culture. Therefore, it is now impossible to envisage Odessa's culture without the Balkan component.

The social and political processes of transformation that have taken place in Odessa in particular and in Ukraine as a whole during the last fifty years have brought about a revival of the national identities of the members of the Balkan peoples in the city. This process has resulted in their involvement in the cultural, social and political life of the city. This suggests that Odessa is the centre of the Balkan diaspora in Ukraine. 


\section{References}

Belousova, Lilia and Volkova, Tatiana 2002. Yevrei Odessy i Yuga Ukrainy [Jews of Odessa and the South of Ukraine]. Gosudarstvennyy arkhiv Odesskoy oblasti; Mezhdunarodnyy yevreyskiy obshchinnyy tsentr 'Migdal'. Odessa: OOO 'Studia 'Negotsiant'. Book 1: late 18th - early 20th cent.

Belousova, Lilia and Berezin, S., et al. 2014. Greki Odessy. Immenoi ukazatel po metricheskim knigam Odesskoi Grecheskoi Sviato-Troitskoi tserkvi [Greeks of Odessa. Name index for the metric books of the Greek Saint Trinity Church] in Series 'Trudy Gosudarstvennogo arkhiva Odesskoy oblasti' V. XXXVIII. Part I. 1799-1831, 1836.

Belousova, Lilia 2017. Nacional 'ni tovarystva v Odesi v XIX - na pochatku XX st. [National Societies in Odessa in the XIX - early XX centuries]. Ukrayins 'ky 'yi istory 'chny'j zhurnal, 2: 46-63.

Berber, Georgi 2019. Greki Odessy - piraty i metsenaty [Greeks of Odessa - pirates and art patrons]. Kyiv: Interservis.

De Ribas, Aleksandr 1995 [1913]. Staraya Odessa [Old Odessa]. Reprintnoe izdanie, Moskva: Dimoff i K.

Dontsova, Tatiana 2016. Moldavanka: zapiski kraeveda [Moldovanka: notes of the local historian]. Odessa: Chernomore.

Gerligi, Patricia 1999. Odessa. Istoriya mista. 1794-1914, [Odessa. History of the city. 1794-1914] Kyiv: Kritika.

Gubar, Oleg 2010a. Funktsii Odesskogo stroitelnogo komiteta v kontekste istorii gradostroitelstva Odessy [Functions of the Odessa Construction Committee in the context of the history of Odessa city planning]. DeribasovskayaRishelevskaya. Literaturno-khudozhestvenny, istoriko-kraevedcheskiy, illyustrirovanny almanakh. Odessa, 40: 20-35.

Gubar, Oleg 2010b. Funktsii Odesskogo stroitelnogo komiteta v kontekste istorii gradostroitelstva Odessy. [Functions of the Odessa Construction Committee in the context of the history of Odessa city planning]. DeribasovskayaRishelevskaya. Literaturno-khudozhestvenny, istoriko-kraevedcheskiy, illyustrirovanny almanakh. Odessa, 43: 20-45.

Ibragimova, Raisa 2010. Kontsept kak universal'noye i natsional'nospetsificheskoye yavleniye [Concept as a universal and nationally specific phenomenon] In: Molodoy uchenyy. Tomsk, 5(16), V. II, pp. 27-30. 
Kalmakan, Nikolay 2002. Malobuyalykskiye greki: 200 let na Odesschine [Maly Buyalyk Greeks: 200 years in the Odessa region]. Odessa: Druk. V.1 200 years of the history of the Greek colony Maly Buyalyk in the Odessa region.

Kisse, Anton 2006. Vozrozhdeniye bolgar Ukrainy [Revival of Bulgarians of Ukraine]. Odessa: Optimum.

Nunes, Olena 2007. Nacional 'no-kul'turni tovary'stva ta organizaciyi Odeshhy 'ny'. [National-cultural societies and organizations of Odessa region]. Dovidny'k. Odessa: ODNB im. M. Gor' kogo.

Ogloblin, Oleksandr 1928. Odes 'ke porto-franko. [Odessa free port] In: Naukovi zapy 'sky' Ky'yivs 'kogo insty'tutu narodnogo gospodarstva. V (9): 36-50.

Prigarin, Aleksandr 2017. Balkanskie substraty v odesskoy kukhne: kulturogenez gorodskoy sistemy pitaniya. [Balkan substrates in Odessa cuisine: cultural genesis of the urban food system]. In: Lozovyuk P. and Prigarin, A. Etnologiya Odessy v istoricheskoy i sovremennoy perspektivakh. Odessa: Irbis, pp. 160-173.

Richardson, Tanya 2008. Kaleidoscopic Odessa: History and Place in Contemporary Ukraine. Toronto, Buffalo and London: University of Toronto Press.

Stanko, Vladimir 2002. Istoriya Odesy'. [History of Odessa]. Odessa: Druk.

Tserovich, Ljubivoje 2002. Srbi u Ukraini. [Serbs in Ukraine]. Novi Sad: Museum Vojvodiне: Srpsko-ukrajinsko drusstvo.

Zhecheva, Anna and Serebryannikova, Natalia 2014. Albantsy [Albanians]. In: Kisse, Anton, Prigarin, Alesandr and Stanko, Vladimir (eds.) Budzhak: istoriko-etnograficheskie ocherki narodov yugo-zapadnykh rayonov Odesshchiny. Odessa: RedOdessa, PostSciptUm, SMIL, pp. 171-190.

\section{Internet Sources}

Asotsyatiya na Blgrite v Ukraina [Association of Bulgarians in Ukraine] Available at: http://abuodes.org.ua/asotsiatsija/asotsiatsijata_tseli/, last accessed on 18.09.2019).

Bolgarskiy restoran s istoriey [Bulgarian restaurant with history] Available at: http:// mehana.od.ua, last accessed on 19.09.2019.

Kesmendzhi P.A. Eti zagadochnye arnauty [These are mysterious arnauts]. Available at: https://rua.gr/greece/history/18490-eti-zagadochnye-arnauty.html, last accessed on 01.10.2019.

Klub bolelshchikov futbola [Football Fans Club]. Ofitsialnyy sayt. Available at: http:// kbf-odessa.org/index.php/istoriya-kluba, last accessed on 13.09.2019. 


\section{Halyna Stoyanova}

Malaya Arnautskaya: 10 interesnykh faktov o samoy znamenitoy ulitse Odessy. [Malaya Arnautskaya: 10 interesting facts about the most famous street of Odessa]. Available at: https://od.vgorode.ua/news/obzory/412488-malaia-arnautskaia-10-ynteresnykh-faktov-o-samoi-znamenytoi-ulytse-odessy, last accessed on 5.10.2018.

Muzey futbola snova gotov prinimat posetiteley. [The Football Museum is ready to receive visitors again.] Odesskaya zhizn. Informatsionnyy gorodskoy portal. Available at: http://odessa-life.od.ua/news/37385-Muzey-futbola-snova-gotovprinimat-posetiteley, last accessed on 13.09.2019.

Odesskiy Bolgarskiy Dramaticheskiy teatr. [Odessa Bulgarian Drama Theater] Ofitsialnyy sayt teatra. Available at: http://www.bgteatr.od.ua/o-nas/, last accessed on 24.09.2019.

Petrova M. Grecheskaya ploshchad (prodolzhenie znakomstva) [Greek Square (continued dating)]. Available at: http://odesskiy.com/ulici-v-istorii/grecheskaja-ploschad-prodolzhenie-znnakomstva.html, last accessed on 26.09.2019.

Restoran Balkani [Restaurant Balkani]. Available at: https://list.in.ua/Рестораны/120768/ Balkani-Одесса, last accessed on 01.10.2019.

$\mathrm{V}$ chem zhe fenomen Odessy? V tom, chto eto ODYe-Ye-S-SA [What is the phenomenon of Odessa? That it is ODE-E-S-SA] Available at: http://odesskiy.com/chisto-fakti-iz-zhizni-i-istorii/v-chyom-zhe-fenomen-odessy-v-tom-chto-eto-ode-e-s-sa. html, last accessed on 15.09.2018.

Vopros-otvet: otkuda proizoshli nazvaniya odesskikh ulits Bolshoy i Maloy Arnautskikh? [Question-answer: where did the names of the Odessa streets of Bolshaya and Malaya Arnautsky come from?] Available at: https://od.vgorode.ua/ news/24/289894-vopros-otvet-otkuda-proyzoshly-nazvanyia-odesskykh-ulytsbolshoi-y-maloi-arnautskykh, last accessed on 21.09.2019.

Stoyanova Halyna, Ph.D. in History, Associate Professor at the Department of Archaeology and Ethnology of Ukraine, Docent, Odessa I. I. Mechnikov National University. Research interests: rituals in the human life cycle of ethnic groups in the South of Ukraine, ethnic stereotypes of behaviour, gender studies in ethnology, ethnography of the city, behavioural strategies of ethnic and social groups in the urban area, anthropology of everyday life. 